Volume 4 Nomor 2, Agustus 2019, halaman 162 - 173

\title{
PEMBELAJARAN MATEMATIKA BERBANTUAN ANDROID UNTUK MENINGKATKAN PEMAHAMAN KONSEP MATEMATIS
}

\section{Android-Based Mathematics Learning to Improve Understanding of Mathematical Concept}

\author{
Meliyana $^{1)}$, Jajang Rahmatudin' ${ }^{2)}$, Rifqi Hidayat ${ }^{3)}$ \\ 1,2,3 Universitas Muhammadiyah Cirebon \\ 1) meliyana242@gmail.com, ${ }^{2)}$ j.rahmatudin87@gmail.com, ${ }^{3)}$ rifqi.math@ gmail.com
}

\begin{abstract}
ABTRAK
Penelitian ini menguji akan kemampuan pemahaman konsep matematis siswa SMK setelah diterapkannya pembelajaran matematika geogebra for mobile apps. Penelitian ini didasari oleh rendahnya pemahaman konsep matematis siswa SMK dalam pembelajaran matematika. Tujuan Penelitian ini adalah untuk mengetahui perbedaan serta peningkatan pemahaman konsep matematis siswa SMK yang pembelajaran matematikanya perbantuan android (aplikasi geogebra) dengan siswa yang pembelajaran matematikanya secara konvensional. Penelitian ini merupakan penelitian Quasi Experimental Design dengan bentuk Nonequivalent Control Group Design. Populasi dalam penelitian ini adalah siswa kelas X SMK Plus Al-Hilal Arjawinangun Kabupaten Cirebon Tahun Pelajaran 2019/2020. Sampel dalam penelitian ini menggunakan teknik sampling purposive. Sampel penelitian melibatkan 30 siswa kelas X Teknik Komputer dan Jaringan (TKJ) sebagai kelas eksperimen dan 30 siswa kelas X Perbankan (PRB) sebagai kelas kontrol Instrumen yang digunakan dalam penelitian ini berupa tes kemampuan pemahaman konsep matematis, lembar observasi guru dan siswa. Analisis data dilakukan secara kuantitatif menggunakan uji Independent Samples T-Test dan uji Mann-Whiney $U$ (non parametric). Hasil penelitian ini menunjukkan bahwa: (1) Kemampuan pemahaman konsep matematis siswa yang pembelajaran nya perbantuan geogebra for mobile apps lebih baik daripada siswa yang pembelajaran nya secara konvensional; (2) Peningkatan pemahaman konsep matematis siswa yang pembelajaran nya perbantuan geogebra for mobile apps lebih baik daripada siswa yang pembelajaran nya secara konvensional.
\end{abstract}

Kata Kunci: Pemahaman Konsep Matematis, Android, dan Geogebra For Mobile Apps.

\section{ABSTRACT}

This study examines the ability of understanding the mathematical concepts of vocational students after the application of android-assisted mathematics learning (geogebra application). This research is based on the lack of understanding of the mathematical concepts of vocational students in learning mathematics. The purpose of this study was to determine the differences and increase understanding of the mathematical concepts of vocational students who are learning mathematics assisted with android (geogebra application) with students who are learning mathematics conventionally. This research is a Quasi Experimental Design research with the form of Nonequivalent Control Group Design. The population students class X SMK Plus Al-Hilal Arjawinangun Cirebon District in 2019/2020 Academic Year. The research sample involved 30 students of class X Computer and Network Engineering (TKJ) as an experimental class and 30 students of class X Banking (PRB) as a control class. The sample students a purposive sampling technique. The instrument used in this study was in the form of a test of the ability to understand mathematical concepts, teacher and student observation sheet. Data analysis was performed quantitatively using the Independent Samples T-Test and the Mann-Whiney U (nonparametric) test. The results of this study indicate that: (1) The ability to understand mathematical concepts of students whose learning is assisted by android (geogebra application) is better than students whose learning is conventional; (2) Improving understanding of mathematical concepts of students whose 
learning is assisted by android (geogebra application) is better than students learning conventionally.

Keywords: Understanding of Mathematical Concepts, Android, and Geogebra For Mobile Apps.

How to Cite: Meliyana, Jajang Rahmatudin, Rifqi Hidayat. (2019). Pembelajaran Matematika Berbantuan Android Untuk Meningkatkan Pemahaman Konsep Matematis. Mathline: Jurnal Matematika dan Pendidikan Matematika, Vol.4, No.2, 162-.

DOI

PENDAHULUAN

Perkembangan ilmu pengetahuan dan teknologi pada saat ini menunjukkan perubahan yang sangat pesat, dengan meningkatnya kebutuhan manusia salah satunya yaitu dunia pendidikan (Budiman , 2017). Pemanfaatan ilmu pengetahuan dan teknologi dalam proses pembelajaran sangat dibutuhkan untuk melakukan pembaharuan, sistem pembelajaran secara konvensional yang dinilai sudah tidak relevan dengan dinamika perkembangan zaman (Husain , 2014). Oleh karena itu, pemanfaatan ilmu pengetahuan dan teknologi dalam dunia pendidikan, salah satunya upaya untuk meningkatkan efektifitas dalam penyampaian ilmu pengetahuan dari proses pembelajaran.

Pendidikan mempunyai peranan yang sangat penting bagi kehidupan manusia. Karena dengan adanya pendidikan, maka manusia akan mempunyai pandangan dan arah hidup yang lebih jelas dan terarah (Siagian, 2016). Terutama dalam pembelajaran matematika. Matematika merupakan mata pelajaran yang harus dipelajari oleh siswa mulai dari tingkat SD, SMP, SMA/ SMK sampai perguruan tinggi, tidak hanya dipelajari saja namun matematika juga diperlukan untuk kegiatan sehari-hari dalam memecahkan masalah (Purnama, Irawan, \& Sa'dijah, 2017).

Salah satu aspek pembelajaran matematika adalah pemahaman konsep matematis. Pemahaman konsep matematis merupakan bagian yang sangat penting dalam proses pembelajaran matematika karena pemahaman konsep matematis dasar untuk berfikir dalam memecahkan masalah yang bertujuan untuk mendukung kemampuan matematika lainnya, seperti komunikasi matematika, penalaran matematis, koneksi matematis, representasi matematis dan masalah pemecahan (Lambertus , 2016). Suatu konsep akan mudah dipahami dan diingat oleh siswa jika konsep tersebut disajikan melalui prosedur dan langkah-langkah yang tepat, jelas dan menarik. 
Permasalahan pendidikan di sekolah merupakan proses nyata yang selalu muncul pada setiap jenjang pendidikan. Hal ini terlihat jelas bagaimana rendahnya prestasi matematika kita dibandingkan dengan negara lain. Terkait permasalahan ini, sebagaimana dengan hasil penelitian PISA (Kemendikbud, 2016 ) menyatakan bahwa:

"Sebanyak 72 negara, termasuk Indonesia, mengikuti Programme for International Student Assessment (PISA) untuk mengevaluasi sistem pendidikan dalam bidang matematika, sains, dan membaca. Program Indonesia National Assessment Program (INAP) pada 2016, itu dilakukan setiap tiga tahun sekali kepada siswa berusia 15 tahun dari sekolah secara acak menunjukkan 20,58\% cukup dan hanya 2,29\% yang kategori baik, sehingga sekitar 77,13\% siswa SD di seluruh Indonesia memiliki kompetensi matematika yang sangat rendah" (Setiyono, 2018).

Selanjutnya analis berdasarkan data Kemendikbud (2019) menyatakan bahwa :

"Mata pelajaran matematika meraih rerata nilai terendah secara nasional yang diikuti oleh peserta UNBK mencapai 1,5 juta murid dari 13.292 satuan pendidikan, yakni hanya 35,25 rerata nilai siswa Sekolah Menengah Kejuruan (SMK) seluruh provinsi sebesar 46,74 dari skala 0-100 untuk tahun ajaran 2018/2019”.

Berdasarkan masalah tersebut, selanjutnya peneliti melakukan observasi data yang didapat dari tata usaha (TU) yang ditemukan di SMK Plus Al-Hilal Arjawinangun hasil nilai Ujian Nasional (UN) tahun ajaran 2018/2019 mata pelajaran matematika dari 53 peserta didik dengan nilai rata-rata sebesar 28,90. Hal ini dapat disimpulkan bahwa nilai hasil belajar matematika di SMK Plus Al-Hilal Arjawinangun masih tergolong rendah.

Berdasarkan permasalahan tersebut dapat dikatakan bahwa pemahaman konsep matematis peserta didik masih tergolong rendah (Hutagalung, 2017). Menurut Husna (2014) mengatakan bahwa pemahaman konsep merupakan kemampuan dasar untuk mencapai kemampuan matematis yang lebih tinggi seperti penalaran, koneksi, komunikasi, representasi, dan pemecahan masalah ( Anika, Hidaya, \& Ediputra, 2018). Sejalan dengan pendapat Abdullah (2015) mengatakan bahwa pemahaman konsep dalam matematika merupakan komponen dasar, kemampuan pemahaman konsep untuk mengukur sejauh mana materi yang dipelajari dapat dikuasai dengan baik (Hikma, 2017). Oleh karena itu, pemahaman konsep matematis memiliki peran penting dalam pembelajaran matematika sehingga pemahaman konsep suatu kemampuan yang perlu diperhatikan.

Selain itu seiring dengan perkembangan teknologi yang berkembang sangat pesat mereka cenderung sulit untuk dipisahkan dari perangkat teknologi misalnya smartphone (Mutia , 2017). Tingkat perkembangan penggunaan smartphone yang semakin tinggi dan 
relatif semakin murah merupakan faktor pendukung penggunaan smartphone di Indonesia sangat berkembang pesat, lembaga riset digital marketing emarketer memperkirakan tahun 2018 jumlah pengguna aktif smartphone lebih dari 100 juta orang termasuk pelajar dengan penggunaan aktif terbesar keempat di dunia setelah Cina, India dan Amerika (Astuti, Dasmo, \& Sumarni , 2018). Hasil survey yang dilakukan oleh Opera tahun 2013 menunjukkan bahwa di Indonesia 10\% pengguna android adalah remaja berusia $13-17$ tahun (Lestari, Senjaya, \& Ismunandar, 2019).

Sesuai dengan pendapat Hess (2014) penggunaan smartphone sangat efektif dalam pembelajaran sebagai media pendukung untuk memahami materi, salah satunya smartphone berbantuan android dapat digunakan di luar atau di dalam kelas sehingga pembelajaran berbantuan android bersifat fleksibel mudah dilakukan dimana saja (Prasetyo et al, 2015). Android merupakan sebuah sistem operasi untuk mobile yang berbantuan linux dan bersifat open source (Supriyono, Saputra, Sudarmllah, \& Darsono , 2014). Beberapa sistem operasi pada android salah satunya application dan widgets sistem ini kegunaannya untuk men download dan menginstal aplikasi di android serta sistem Open Development Platform ini menawarkan pengguna android untuk mengembangkan aplikasi yang lebih inovatif (Hadinata \& Bakti, 2017).

Adanya sistem Open Development Platform dalam dunia pendidikan, salah satunya adalah aplikasi matematika yang bisa download dan bisa terinstal di smartphone berbantuan android yaitu aplikasi geogebra versi 5.0. Aplikasi geogebra merupakan aplikasi yang bersifat dinamis dan interaktif dapat mengeksplorasi terhadap konsep matematika, peserta didik dengan mudah men download secara gratis dan dapat digunakan secara individu maupun kelompok (Pratiwi , 2016).

Berdasarkan pendapat Astuti, Dasmo, \& Sumarni (2018) menyatakan bahwa sebagian besar peserta didik sudah menggunakan smartphone berbantuan android. Akan tetapi kenyataan yang ditemukan di lapangan sebagian besar peserta didik memanfaatkan smartphone hanya sebatas untuk telepon, SMS, memutar lagu dan video, mengakses social network Facebook, twitter, BBM bahkan bermain game (Supratman, 2018).

Prayudi (2014) mengatakan bahwa penggunaan smartphone seakan-akan memiliki dunianya sendiri, terlihat sibuk dengan smartphone sehingga justru peserta didik terlihat jarang bersosialisasi dengan orang-orang di sekitarnya serta tertanam rasa anti-sosial di kehidupan nyata (Muflih, Hamzah, \& Puniawan, 2017). Kebiasaan peserta didik yang sibuk dengan smartphone akan membuat keaktifan peserta didik menjadi sangat rendah dan tidak memberi kemungkinan bagi peserta didik untuk berpikir serta berpartisipasi aktif 
secara penuh dan berdampak buruk pada prestasi belajar peserta didik menurun salah satunya pada mata pelajaran matematika.

Salah satu upaya untuk meningkatkan mutu pendidikan guru harus bisa mempengaruhi pemahaman konsep matematis siswa, dalam dunia pendidikan sangat penting untuk menumbuhkan pemahaman konsep matematis siswa dalam meningkatkan prestasi belajar. Upaya untuk meningkatkan pemahaman konsep matematis dengan menerapakan pembelajaran matematika menggunakan pembelajaran inkuiri berbantuan android: (1) Apakah pemahaman konsep matematis siswa yang pembelajaran menerapkan pembelajaran matematika menggunakan pembelajaran inkuiri berbantuan android lebih baik daripada siswa yang pembelajaran secara konvensional ?; (2) Apakah peningkatan pemahaman konsep matematis yang pembelajaran nya menerapkan pembelajaran menggunakan pembelajaran inkuiri berbantuan android lebih baik daripada siswa yang pembelajaran secara konvensional ? serta bertujuan untuk mengetahui perbedaan dan peningkatan sebelum dan sesudah diterapkannya pembelajaran menggunakan pembelajaran inkuiri berbantuan android.

Pemahaman konsep matematis dalam penelitian ini diterapkan tiga indikator pemahaman konsep matematis yaitu: 1) Menyatakan ulang sebuah konsep, 2) Menyajikan konsep dengan bentuk representasi matematis, dan 3) Mengaplikasikan konsep atau algoritma dalam pemecahan masalah (Mawaddah \& Maryanti, 2016). Model pembelajaran yang digunakan model inkuiri dengan sintak yaitu: 1) Menyajikan pertanyaan, 2) Membuat hipotesis, 3) Merancang percobaan, 4) Melakukan percobaan untuk memperoleh informasi, 5) Mengumpulkan dan menganalisis data, dan 6) Membuat kesimpulan (Lahadisi, 2014).

\section{METODE PENELITIAN}

Metode penelitian ini menggunakan metode kuantitatif, penerapan penelitian ini menggunakan metode Desain Quasi Experimental Design, dengan menguji coba langsung terhadap sampel yang ditentukan. Desain penelitian menggunakan Nonequivalent Control Group Design penelitian terdapat dua kelompok penelitian yaitu kelas eksperimen dan kontrol yang diberikan pre-test, treatment dan post-test (Sugiyono, 2018). Treatment yang diberikan yaitu menerapkan pembelajaran matematika menggunakan pembelajaran inkuiri berbantuan android pada kelas eksperimen sedangkan kelas kontrol menggunakan model pembelajaran konvensional.

Sampel penelitian diambil dengan teknik sampling purposive merupakan teknik penentuan sampel dengan pertimbangan tertentu (Sugiyono, 2018) yaitu kelas X TKJ 
(Teknik Komputer dan Jaringan) sebagai kelas eksperimen yang terdiri dari 30 siswa menerapkan pembelajaran matematika menggunakan pembelajaran inkuiri berbantuan android sedangkan pada kelas X PRB (Perbankan) yang terdiri dari 30 siswa sebagai kelas kontrol yang pembelajaran nya secara konvensional.

Analisis data penelitian ini menggunakan Uji T dengan taraf signifikansi 5\% untuk mengetahui hasil akhir dari pengujian hipotesis yang telah ditetapkan. Peneliti melakukan uji normalitas dan uji homogenitas sebagai prasyarat untuk melakukan uji hipotesis menggunakan statistik para metrik. Uji analisis data pada penelitian ini dilakukan dengan bantuan SPSS for Windows Versi 22.

\section{HASIL DAN PEMBAHASAN}

Berdasarkan hasil penelitian sebelumnya yang dilakukan oleh beberapa peneliti lainnya bahwa penggunaan model inkuiri berbantuan android dalam pembelajaran matematika dapat meningkatkan pemahaman konsep matematis siswa. Begitu pun dari hasil penelitian yang dilakukan dalam penelitian ini menujukan bahwa hasil dari penelitian menunjukkan bahwa model pembelajaran inkuiri berbantuan android dapat meningkatkan pemahaman konsep matematis siswa.

Sesuai dari hasil deskriptif data pre-test kelas eksperimen dan kontrol memiliki nilai yang tidak terpaut jauh, berbeda dengan hasil deskriptif data post-test yang memiliki perbedaan cukup signifikan. Adapun hasil secara umum dari pre-test dan post-test sebagai berikut:

Tabel 1

Hasil Deskriptif Pre-Test dan Post-Test

\begin{tabular}{|cllcccc|}
\hline \multirow{2}{*}{ Data } & \multicolumn{1}{c}{ Kelas } & N & Min & Max & Mean & Std Deviasi \\
\hline \multirow{2}{*}{ Pre-Test } & Ekperimen & 30 & 2 & 10 & 6,17 & 1,821 \\
\cline { 2 - 7 } & Kontrol & 30 & 1 & 10 & 4,97 & 2,141 \\
\hline \multirow{2}{*}{ Post-Test } & Ekperimen & 30 & 6 & 15 & 11,13 & 1,852 \\
\cline { 2 - 7 } & Kontrol & 30 & 1 & 12 & 8,60 & 3,158 \\
\hline
\end{tabular}

Berikut adalah diagram yang menggambarkan secara umum hasil deskriptif data pre-test dan post-test. 


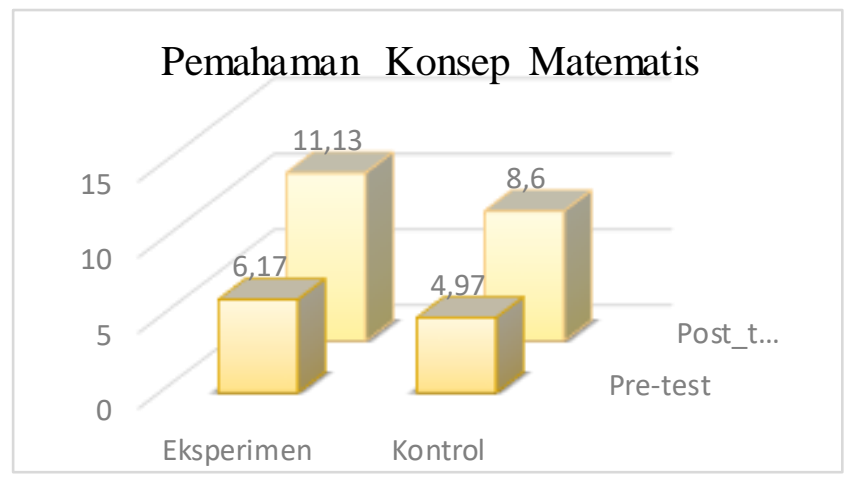

Grafik 1. Deskriptif Data Pre-test dan Post-test

Berdasarkan tabel dan grafik di atas, dapat dilihat bahwa kemampuan awal pemahaman konsep matematis siswa kelas eksperimen dan kontrol berbeda yaitu selisih 1,2, sedangkan kemampuan akhir pemahaman konsep matematis siswa kelas eksperimen dan kontrol memiliki selisih 2.53. Maka pada kemampuan akhir pemahaman konsep matematis siswa terdapat perbedaan yang signifikan walaupun kemampuan awal pemahaman konsep matematis siswa tidak jauh berbeda. Pada penelitian ini terdapat dua permasalahan yang diteliti yaitu perbedaan kemampuan pemahaman konsep matematis siswa dan peningkatan kemampuan pemahaman konsep matematis siswa. Adapun mengenai hasil secara lebih rinci yaitu sebagai berikut.

\section{Kemampuan Pemahaman Konsep Matematis}

Penelitian dilakukan dengan menerapkan dua perlakuan yang berbeda di dua kelas. Kelas eksperimen menggunakan pembelajaran inkuiri berbantuan android, sedangkan kelas kontrol menggunakan pembelajaran konvensional. Dari hasil pre-test dan juga post-test akan diuji normalitas dan homogenitas sebagai uji prasyarat untuk melakukan uji hipotesis atau uji rerata persamaan pre-test dan uji rerata perbedaan post-test.

Pengujian hipotesis dilakukan setelah uji prasyarat telah memenuhi. Berikut merupakan hasil dari uji normalitas data pre-test dan post-test:

\section{Tabel 2}

Data Hasil Uji Normalitas Nilai Pre-Test dan Post-Test Pemahaman Konsep Matemtis

\begin{tabular}{|clccc|}
\hline \multirow{2}{*}{ Data } & \multirow{2}{*}{ Kelas } & \multicolumn{2}{c}{ Shapiro-Wilk } & \multirow{2}{*}{ Kesimpulan } \\
\cline { 2 - 4 } Pre-test & Eksperimen & 0,933 & 0,059 & Berdistribusi Normal \\
\cline { 2 - 5 } & Kontrol & 0,956 & 0,237 & Berdistribusi Normal \\
\hline \multirow{2}{*}{ Post-test } & Eksperimen & 0,746 & 0,000 & Tidak Berdistribusi Normal \\
\cline { 2 - 4 } & Kontrol & 0,774 & 0,000 & Tidak Berdistribusi Normal \\
\hline
\end{tabular}


Setelah dilakukan uji normalitas, diperoleh data pre-test terdistribusi normal dan post-test tidak terdistribusi normal sehingga tahap selanjutnya dilakukan uji homogenitas. Uji homogenitas dilakukan melalui uji $F$ atau Levine's test menggunakan taraf signifikansi $\alpha=0,05$, maka kriteria pengambilan keputusannya yaitu jika nilai signifikansinya $\geq 0,05$ maka $H_{0}$ diterima, sedangkan jika nilai signifikansi nya $<0,05$ maka $H_{0}$ ditolak. Berikut hasil uji homogenitas Levine's Statistic data pre-tes.

\section{Tabel 3}

Data Hasil Uji Homogenitas Data Pre-test Kemampuan Pemahaman Konsep Matematis

\begin{tabular}{|cccc|}
\hline \multirow{2}{*}{ Data } & \multicolumn{2}{c}{ Levene Statistic } & Keterangan \\
\cline { 2 - 3 } Pre-Test & 1,747 & 0,191 & Bervariasi Homogen \\
\hline
\end{tabular}

Berdasarkan tabel di atas, terlihat bahwa pengujian prasyarat terpenuhi sehingga pengujian pre-test menggunakan statistik para metrik Uji T-Test dan pengujian post-test menggunakan statistik nonparametric Uji Mann Whitney $U$ dengan signifikansi 0,05. Berikut merupakan hasil dari analisis data:

Tabel 4

Hasil Uji Rerata Pre-test Pemahaman Konsep Matematis

\begin{tabular}{|ccc|}
\hline \multirow{2}{*}{ Data } & $\begin{array}{c}\text { Independent Samples } \text { T- } \\
\text { Test }\end{array}$ & Kesimpulan \\
\cline { 2 - 2 } & Sig (2-Tailed) & \\
\cline { 2 - 2 } Pre- & 0,023 & $\mathrm{H}_{0}$ Diterima \\
test & & \\
\hline
\end{tabular}

Berdasarkan tabel di atas hasil uji rerata pre-test kemampuan pemahaman konsep matematis siswa, diperoleh nilai Sig. (1-tailed) sebesar 0,0115. Maka $\mathrm{H}_{0}$ diterima, artinya tidak terdapat perbedaan nilai pre-test kemampuan pemahaman konsep matematis siswa kelas eksperimen dengan kelas kontrol. Kemudian, akan dilakukan analisis uji rerata perbedaan post-test dengan hasil sebagai berikut:

\section{Tabel 5}

Hasil Uji Rerata Post-test Pemahaman Konsep Matematis

\begin{tabular}{|ccc|}
\hline \multirow{2}{*}{ Data } & Mann Whitney $\boldsymbol{U}$ & Kesimpulan \\
\cline { 2 - 3 } Post-test & Sig (2-Tailed) & \\
\hline
\end{tabular}

Berdasarkan tabel di atas, Pengujian data rerata perbedaan post-test test kemampuan pemahaman konsep matematis siswa, diperoleh nilai Sig. (1-tailed) sebesar 0,0005 maka 
$\mathrm{H}_{0}$ ditolak, artinya terdapat perbedaan nilai pre-test kemampuan pemahaman konsep matematis siswa kelas eksperimen dengan kelas kontrol.

Dilihat dari hasil uji persamaan pre-test dan uji perbedaan post-test menunjukkan bahwa kemampuan pemahaman konsep matematis siswa pada mulanya setara atau tidak terdapat perbedaan yang signifikan, akan tetapi setelah memperoleh perlakuan kemampuan pemahaman konsep matematis siswa terdapat perbedaan yang signifikan. Maka dapat disimpulkan bahwa terdapat perbedaan kemampuan pemahaman konsep matematis siswa yang menggunakan pembelajaran inkuiri berbantuan android dengan siswa yang menggunakan pembelajaran konvensional.

\section{Peningkatan Kemampuan Pemahaman Konsep Matematis}

Peningkatan kemampuan pemahaman konsep matematis siswa dapat dilihat dari hasil akhir nilai post-test melalui Analisis skor N-Gain. Uji hipotesis N-Gain dilakukan setelah uji prasyarat telah terpenuhi yaitu uji normalitas dan uji homogenitas. Uji normalitas skor $N$-Gain test pada penelitian ini menggunakan uji Shapiro-Wilk karena jumlah siswa kedua kelas yaitu lebih dari 30 siswa. Uji Shapiro-Wilk dilakukan dengan bantuan Software SPSS Versi 22 for Windows. Taraf signifikansi yang digunakan dalam uji normalitas $N$-Gain Test yaitu $\alpha=0,05$. Berdasarkan taraf signifikansi yang digunakan maka kriteria pengambilan keputusannya yaitu jika nilai signifikansi $\geq 0,05$ maka $H_{0}$ diterima, sedangkan jika nilai signifikansi $<0,05$ maka $H_{0}$ ditolak. Berikut hasil uji normalitas Shapiro-Wilk data N-Gain secara umum :

\section{Tabel 6}

\section{Data Hasil Uji Normalitas Nilai $N$-Gain}

Pemahaman Kosep Matematis

\begin{tabular}{|cccccc|}
\hline \multirow{2}{*}{ Data } & \multirow{2}{*}{ Kelas } & \multirow{2}{*}{$\mathbf{N}$} & \multicolumn{2}{c}{ Shapiro-Wilk } & \multirow{2}{*}{ Keterangan } \\
\cline { 4 - 5 }$N$ N-gain & Ekperimen & 30 & 0,937 & 0,75 & Distribusi Normal \\
\cline { 2 - 5 } & Kontrol & 30 & 0,921 & 0,28 & Tidak Distribusi Normal \\
\hline
\end{tabular}

Setelah dilakukan uji normalitas, diperoleh data $\mathrm{N}$-Gain yang kelas eksperimen berdistribusi normal dan kelas kontrol tidak berdistribusi normal sehingga tahap selanjutnya dilakukan uji non parametrik. Uji Mann-Whitney $U$ dilakukan menggunakan taraf signifikansi $\alpha=0,05$, maka kriteria pengambilan keputusannya yaitu jika nilai signifikansinya $\geq 0,05$ maka $H_{0}$ diterima, sedangkan jika nilai signifikansi nya $<0,05$ maka $H_{0}$ ditolak. Berikut hasil uji Uji Mann-Whitney $U$ data $N$-Gain sebagai berikut: 


\section{Tabel 7}

Hasil Uji Mann-Whitney U Data N-gain

\begin{tabular}{|c|c|c|c|}
\hline \multirow{2}{*}{ Data } & \multicolumn{2}{|c|}{ Mann-Whitney $\boldsymbol{U}$} & \multirow{2}{*}{ Keterangan } \\
\cline { 2 - 3 } & $\boldsymbol{T}$ & Sig (2-Tailed) & \\
\hline N-Gaint & 233,5 & 0,001 & $H_{0}$ ditolak \\
\hline
\end{tabular}

Berdasarkan tabel di atas, hasil dari analisis uji rerata perbedaan $N$-Gain memperoleh nilai sig. $0,001<0,05$ sehingga $H_{0}$ ditolak. Maka dari hasil analsis tersebut terdapat peningkatan kemampuan pemahaman konsep matematis siswa yang menggunakan pembelajaran inkuiri berbantuan android lebih baik daripada siswa yang menggunakan pembelajaran konvensional.

\section{Tabel 8}

Kriteria $N$-Gain

Penerapan Model Inkuiri Berbantuan Android

\begin{tabular}{|l|l|l|l|l|}
\hline Data & Kelas & $\mathbf{N}$ & Mean & $\begin{array}{l}\text { Kriteri } \\
\text { a }\end{array}$ \\
\hline \multirow{2}{*}{$N$-Gain } & Eksperimen & 30 & 37,72 & Sedang \\
\cline { 2 - 5 } & Kontrol & 30 & 23,28 & Rendah \\
\hline
\end{tabular}

Dilihat dari uji analisis data yang telah dilakukan maka dapat dikatakan bahwa kemampuan pemahaman konsep matematis siswa kelas eksperimen lebih tinggi dengan menggunakan pembelajaran inkuiri berbantuan android lebih baik daripada pembelajaran yang konvensional. Dari hasil analisis tersebut juga dapat disimpulkan bahwa penerapan pembelajaran inkuiri berbantuan android dapat meningkatkan kemampuan bahwa kemampuan pemahaman konsep matematis siswa lebih baik daripada pembelajaran konvensional.

\section{KESIMPULAN}

Berdasarkan hasil penelitian yang telah dilakukan pada siswa SMK Plus Al-Hilal Arjawinangun di kelas X Perbankan (PRB) dan kelas X Teknik Komputer dan Jaringan (TKJ), maka dapat diambil kesimpulan bahwa penerapan pembelajaran inkuiri berbantuan android sebagai berikut:

1. Pemahaman konsep matematis siswa yang menerapkan inkuiri berbantuan android lebih baik daripada pembelajaran yang secara konvensional

2. Peningkatan pemahaman konsep matematis siswa yang menerapkan pembelajaran inkuiri berbantuan android lebih baik daripada pembelajaran secara konvensional. 


\section{DAFTAR PUSTAKA}

Anika, E., Hidaya, A., \& Ediputra, K. (2018). Kemampuan Pemahaman Konsep Matematis Siswa Kelas. Jurnal Pendidikan Matematika E-ISSN 2579-9258, Hal 102.

Astuti, I. A., Dasmo, \& Sumarni , R. A. (2018). Pengembangan Media Pembelajaran Berbasis Android Dengan Menggunakan Aplikasi Applied Di SMK Bina Mandiri Depok. Jurnal Pengabdian Kepada Masyarakat (JPKM), Vol 24, Hal 696. Diakses http://jurnal.unimed.ac.id/2012/index.php/jpkm/article/view/10525.

Budiman , H. (2017). Peran Teknologi Informasi dan Komunikasi Dalam Pendidikan. AlTadzkiyyah Jurnal Pendidikan Islam, Hal 31. Diakses http://ejournal.radenintan.ac.id/index.php/tadzkiyyah/article/download/2095/.

Hadinata, N., \& Bakt, A. M. (2017). Location Base Service fasilitas Pendidikan Di Kota palembang Berbasis Android. Jurnal Informatika ISSN :2407-1730, Hal 2. Diakses http://eprints.binadarma.ac.id/3218/1/penelitian_novri_takin.pdf.

Hikmah , R. (2017). Penerapan Model Advance Organizer Untuk Meningkatkan Kemampuan Pemahaman Konsep Matematis. Jurnal SAP e-ISSN: 2549-2845, Hal 272.

Diakses https://www.google.com/url?sa=t\&rct=j\&q=\&esrc=s\&source=web\&cd=2\&cad=rja \&uact=8\&ved=2ahUKEwi02j6z9nlAhXRgeYKHSjnBmYQFjABegQIAhAC\&url= https\%3A\%2F\%2Fjournal.lppmunindra.ac.id\%2Findex.php\%2FSAP\%2Farticle\%2 Fdownload\%2F1204\%2F1227\&usg=Aovvaw2hrd0jky6ym9yxfcy-f6aw.

Husain , C. (2014). Pemanfaatan Teknologi Informasi dan Komunikasi dalam Pembelajaran di SMA Muhammadiyah Tarakan. Jurnal Kebijakan dan Pengembangan Pendidikan EISSN: 2337-7615, Hal 185. Diakses http://ejournal.umm.ac.id/index.php/jmkpp/article/viewFile/1917/2022

Hutagalung, R. (2017). Peningkatan Kemampuan Pemahaman Konsep Matematis Siswa Melalui Pembelajaran Guided Discovery Berbasis Budaya Toba Di Smp Negeri 1 Tukka. MES (Journal of Mathematics Education and Science) ISSN: 2579-6550 (online), Hal $71 . \quad$ Diakses https://www.google.com/url? sa=t\&rct=j\&q=\&esrc=s\&source=web\&cd=1\&cad=rja \&uact=8\&ved=2ahUKEwigjaiuyNnlAhUU6nMBHcSDCg4QFjAAegQIABAC\&ur $\mathrm{l}=\mathrm{https} \% 3 \mathrm{~A} \% 2 \mathrm{~F} \% 2 \mathrm{Fjurnal} . u i s u . a c . i d \% 2$ Findex.php $\% 2 \mathrm{Fmesuisu} \% 2 \mathrm{Farticle} \% 2 \mathrm{Fvie}$ w\%2F133\%2F110\&usg=AOvVaw2TgGH2ZRxKku5VW111LwNl

Kemendikbud. (2018). Hasil Ujian Nasional Tahun 2017. Jakarta. Tersedia: www.radarcirebon.com/nilai-rata-rata-ujian-nasional-sma-jeblok.html. diakses: [22 Oktober 2019].

Lahadisi. (2014). Inkuiri: Sebuah Strategi Menuju Pembelajaran Bermakna. Jurnal AlTa'dib, Hal 91.Diakses http://ejournal.iainkendari.ac.id/al-tadib/article/view/319.

Lambertus . (2016). Developing Skills Understanding Of Mathematical High School Student. International Journal of Education and Research ISSN: 2411-5681, Hal 315. Diakses https://www.ijern.com/journal/2016/July-2016/25.pdf

Lestari, A. I., Senjaya, A. J., \& Ismunandar, D. (2019). Pengembangan Media Pembelajaran Berbasis Android Menggunakan Appy Pie untuk Melatih Pemahaman Konsep Turunan Fungsi Aljabar. Pedagogy, 4(2), 1-9.

Mawaddah, S., \& Maryanti, R. (2016). Kemampuan Pemahaman Konsep Matematis Siswa SMP Dalam Pembelajaran Menggunakan Model Penemuan Terbimbing (Discovery Learning). Jurnal EDU-MAT. Diakses https://ppjp.ulm.ac.id/journal/index.php/edumat/article/download/2292/2010 
Muflih, M., Hamzah, H., \& Puniawan, W. A. (2017). Penggunaan Smartphone Dan Interaksi Sosial Pada Remaja Di Sma Negeri I Kalasan Sleman Yogyakarta. Idea Nursing Journal e-ISSN : 2580 - 2445, Hal 13.

Mutia , T. (2017). Generasi Millennial, Instagram dan Dramaturgi suatu Fenomena Dalam Pengelolaan Pesan Ditinjau Dari Perspektif Komunikasi Islam. Jurnal An-nida' ISSN 0853116, Vol 41, Hal 240-251. http//www.gogle.com/jurnalgenererasigadgettJpdf.

Nilai Ujian Nasional SMK Tingkat Nasional Tahun Ajaran 2018/2019. https://databoks.katadata.co.id/datapublish/2019/06/28/berapa-nilai-ujian-nasionalsmk-tingkat-nasional-tahun-ajaran-20182019.

Pratiwi , D. D. (2016). ). Pembelajaran Learning Cycle 5e berbantuan Geogebra terhadap Kemampuan Pemahaman Konsep Matematis. Jurnal Pendidikan Matematika, Hal 191-202. Diakses https://docplayer.info/57764868-Pembelajaran-learning-cycle-5eberbantuan-geogebra-terhadap-kemampuan-pemahaman-konsep-matematis.html

Purnama, M. D., Irawan, E. B., \& Sa'dijah, C. (2017). Pengembangan Media Box Mengenal Bilangan Dan Operasinya Bagi Siswa Kelas 1 Di Sdn Gadang 1 Kota Malang. Jurnal Kajian Pembelajaran Matematika (JKPM) ISSN: 2549 -8584 (online), Hal 46.Supratman, L. P. (2018). Penggunaan Media Sosial oleh Digital Native. Jurnal Informatika , Hal 49. Diakses http://journal2.um.ac.id/index.php/jkpm.

Setiyono, A. (2018). Indonesia Gawat Darurat Matematika. [Online] Tersedia: http://nasional.sindonews.com. Diakses [02 September 2019].

Siagian, M. D. (2016). Kemampuan Koneksi Matematis Dalam Pembelajaran Matematika. MES (Journal of Mathematics Education and Science), Hal 58. Diakses https://www.google.com/url? sa=t\&rct=j\&q=\&esrc=s\&source=web\&cd=2\&cad=rja \&uact=8\&ved=2ahUKEwjzITK4ujlAhWOF3IKHelEAAQQFjABegQIBBAC\&url =https\%3A\%2F\%2Fjurnal.uisu.ac.id\%2Findex.php\%2Fmesuisu\%2Farticle\%2Fvie w\%2F117\%2F94\&usg=AOvVaw1RCoCE9E8gjFv6sXQTcomY.

Sugiyono. (2018). Metode Penelitian Pendidikan. Bandung: Alfa beta.

Supriyono, H., Saputra, A. N., Sudarmllah, E., \& Darsono , R. (2014). Rancang Bangun Aplikasi Pembelajaran Hadis Untuk Perangkat Mobile Berbasis Android. JURNAL 